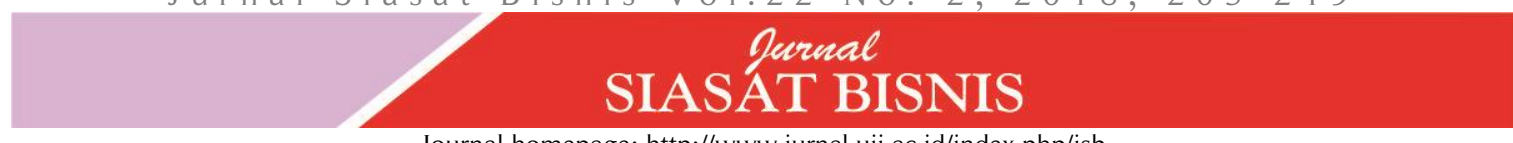

Journal homepage: http://www.jurnal.uii.ac.id/index.php/jsb

\title{
Anteseden dan konsekuen strategi lingkungan proaktif pada perusahaan di Indonesia
}

\author{
Arini Lukita Ismiranti ${ }^{1} \&$ Amin Wibowo ${ }^{2}$ \\ Fakultas Ekonomika dan Bisnis, Universitas Gadjah Mada Yogyakarta \\ e-mail: ${ }^{1}$ arini.230193@gmail.com, ${ }^{2}$ aminwibowo@ugm.ac.id
}

\begin{abstract}
Since the agreements of Environmental Sustainability Development (ESD) was initiated, environment issue has become an essential concern for daily business activities. This leads corporates to implement environmental strategy, especially in the proactive manner. The aim of this study is to investigate the effect of institutional pressures on proactive environmental practices and to examine the implication of proactive strategy to the corporate reputation. Using survey data from 76 companies in Indonesia, multiple regression analysis showed that pressure from competitors and professional networks positively influenced proactive strategies, while regulatory pressure did not influence proactive strategies. Our evidence implied that external factors from competitors and professional networks pressures were important driving forces for corporates to apply proactive strategies. In addition, this study found a positive influence of proactive strategy on corporate reputation.
\end{abstract}

Keywords: Proactive environmental strategy, environmental performance, environmental strategy, corporate reputation.

Abstrak

Sejak kesepakatan Environmental Sustainability Development (ESD) diinisiasi,masalah lingkungan hidup telah menjadi unsur penting perusahaan dalam melakukan aktivitas bisnis. Hal ini mendorong perusahaan unutuk menerapkan strategi berwawasan ramah lingkungan khususnya yang bersifat proaktif. Penelitian ini bertujuan untuk mengetahui pengaruh tekanan institusional terhadap strategi lingkungan proaktif dan implikasinya terhadap reputasi perusahaan. Dengan menggunakan data survei dari 76 perusahaan di Indonesia, hasil analisis regresi berganda menunjukkan faktor eksternal yang bersumber dari tekanan pesaing dan jaringan profesional merupakan faktor pendorong penting bagi perusahaan di Indonesia dalam menerapkan strategi proaktif. Selain itu, penelitian ini juga menemukan adanya pengaruh positif penggunaan strategi proaktif pada reputasi perusahaan.

Kata Kunci: Strategi lingkungan proaktif, kinerja lingkungan, strategi lingkungan, reputasi perusahaan. JEL: M19 DOI: 10.20885/jsb.vol22.iss2.art6

\section{Pendahuluan}

Pesatnya industrialisasi menyebabkan banyak masalah lingkungan yang kompleks, seperti menipisnya sumber daya alam, degradasi ekosistem dan polusi (Liu, Guo, \& Chi, 2015). Masalah ini telah menarik perhatian serius dunia sejak laporan Komisi World Commission on Environmental and Development (WCED) menghasilkan kesepakatan untuk mengatasi masalah lingkungan yang dikenal dengan Environmental Sustainability Development (ESD) (Colwell \& Joshi, 2013). Kesepakatan ini berimplikasi pada berubahnya paradigma kompetisi bisnis saat ini, dimana faktor "lingkungan hidup" telah menjadi unsur penting perusahaan dalam melakukan aktivitas bisnisnya, sehingga banyak perusahaan telah menggunakan strategi lingkungan untuk menciptakan keuntungan dan keunggulan daya saing (González-Benito \& González-Benito, 2006; Ates, Bloemhof, Van Raaij, \& Wynstra, 2012; Liu et al., 2015) tidak terkecuali perusahaan di Indonesia.

Strategi lingkungan dalam literatur manajemen terdiri dari strategi reaktif dan strategi proaktif. Strategi reaktif atau Tindakan Ramah Lingkungan Reaktif (TRLR) adalah strategi 
pengelolaan lingkungan perusahaan secara pasif dalam bentuk pengedalian limbah (pollution control) yang bertujuan untuk mencapai standar pemerintah (Russo \& Fouts, 1997). Sebaliknya, strategi reaktif atau Tindakan Ramah Lingkungan Proaktif (TRLP) adalah strategi pengelolaan lingkungan perusahaan secara aktif dalam bentuk pencegahan limbah (pollution prevention) dengan menerapkan prinsip-prinsip perbaikan lingkungan di seluruh aktivitasnya yang melebihi standar yang ditetapkan pemerintah (beyond compliance) (Menguc, Auh, \& Ozanne, 2010).

Data dari lembaga Program Penilaian Peringkat Kinerja Perusahaan dalam Pengelolaan Lingkungan Hidup (PROPER) menunjukkan adanya signifikansi peningkatan jumlah perusahaan Indonesia yang telah melakukan TRLP sejak tahun 2002 hingga tahun 2015 yaitu dari 8 perusahaan menjadi 108 perusahaan (PROPER, 2015). Bahkan di tahun 2016, tingkat ketaatan dengan predikat perusahaan proaktif mencapai 172 perusahaan (PROPER, 2016). Fakta ini menunjukkan bahwa terjadi peningkatan kesadaran bagi pelaku bisnis di Indonesia untuk mengelola masalah lingkungan sebagai bagian dari aktivitas bisnisnya melalui penerapan strategi proaktif (TRLP). Untuk itu menjadi menarik menyelidiki apa yang mendorong para pelaku bisnis di Indonesia untuk menerapkan strategi proaktif (TRLP) serta bagaimana dampak tindakan ini terhadap kinerja perusahaan.

Meskipun penelitian yang mengkaji anteseden TRLP telah banyak dilakukan, Liu, Guo, dan Chi (2015) mengemukakan bahwa faktor kontingensi nasional yang melekat pada suatu negara atau wilayah dapat memberikan efek yang berbeda dalam menjelaskan hubungan di antara anteseden, TRLP, dan kinerja perusahaan. Selain itu, masing-masing wilayah memiliki potensi polusi yang berbeda dan tunduk pada pengawasan yang berbeda baik dari institusi, kelompok sosial, dan konsumen (González-Benito \& González-Benito, 2006). Sehingga, menyelidiki variabel anteseden dan konsekuen pada konteks wilayah yang berbeda tetap perlu dilakukan apalagi penelitian dengan topik yang sama pada konteks wilayah Indonesia masih sangat terbatas. Selanjutnya pada studi konsekuen, beberapa peneliti telah mengajukan beberapa preposisi mengenai adanya hubungan positif antara strategi proaktif dan reputasi perusahaan (Delmas \& Toffel, 2004; Liu et al., 2015) tetapi bukti empiris mengenai hubungan keduanya masih terbatas (Yang, Hong, \& Modi, 2011). Menyadari hal ini, maka studi hubungan antara TRLP terhadap reputasi perusahaan dianggap memiliki urgensi tersendiri.

Melalui mekanisme isomorfisme, penelitian ini akan menyelidiki bagaimana peran lingkungan institusional perusahaan dapat mendorong penerapan TRLP di Indonesia dengan melibatkan tiga anteseden penting yaitu tekanan koersif, tekanan mimikri, dan tekanan normatif (DiMaggio \&Powell, 1983). Ketiga variabel dipilih karena dianggap dapat merepresentasikan tekanan eksternal dari berbagai pemangku kepentingan dimana penelitian sebelumnya hanya melibatkan beberapa tekanan institusional tertentu (Rivera, 2004; Clemens \& Douglas, 2006; Testa, Gusmerottia, Corsini, Passetti, \& Iraldo, 2015; Yang, Wang, Zhou, \& Jiang, 2018). Literatur yang berkembang saat ini belum mempertimbangkan konsekuensi dari perbedaan berbagai kelompok pemangku kepentingan dalam menjelaskan anteseden TRLP (Hart \& Dowell, 2011; Carballo-Penela \& Castromán-Diz, 2014) dimana masing-masing tekanan institusional dapat memberikan konsekuensi yang beragam pada keputusan strategi TRLP (Jennings \& Zandbergen, 1995). Untuk menjelaskan bagaimana pengaruh tekanan institusional terhadap TRLP, penelitian ini akan menggunakan teori institusional. Menurut Chen, Watson, Boudreau, dan Karahanna (2009), teori institusional dapat memberikan pemahaman yang kompleks bagaimana mekanisme logis suatu perusahaan menjadi homogen (isomorfis) di bawah tekanan sosialnya. Selain itu, teori institusional dapat memberikan uraian yang komprehensif mengenai konteks di mana perusahaan beroperasi (Liu, Liu, Shishime, Yu, $\mathrm{Bi}$, \& Fujitsuka, 2010).

Pengaruh TRLP terhadap reputasi perusahaan dijelaskan melalui kerangka teori sinyal. Menurut Walker (2010), teori sinyal paling tepat dalam menjelaskan pembentukan reputasi khususnya pada penelitian dengan topik kinerja sosial perusahaan. Mengadopsi suatu perilaku sukarela tertentu untuk menyesuaikan dengan industri dapat mencerminkan keinginan strategis perusahaan untuk mempertahankan atau memeroleh reputasi positif di dalam lingkungan institusional mereka (Wright 
\& Rwabizambagu, 2006). Bahkan membangun reputasi sendiri telah dianggap sebagai salah satu keharusan perusahaan dalam strategi lingkungannya (Kumar, 2018). Perusahaan yang menjalankan TRLP dapat dilihat sebagai sinyal strategi yang digunakan perusahaan tersebut untuk membentuk atau mempertahankan reputasi perusahaan.

Secara singkat, penelitian ini memiliki dua tujuan utama yaitu untuk menguji bagaimana pengaruh variabel tekanan koersif, tekanan mimikri, dan tekanan normatif terhadap TRLP dan untuk menguji bagaimana pengaruh variabel TRLP terhadap reputasi perusahaan.

\section{Tinjauan Literatur dan Hipotesis}

\section{Tindakan Ramah Lingkungan Proaktif (TRLP)}

Konsep strategi lingkungan proaktif yang berakar dalam literatur manajemen dipahami sebagai pengurangan dampak kerusakan lingkungan dari aktifitas bisnis dan upaya mengelola bisnis dan alam melebihi standar kepatuhan (Aragón-Correa, 1998). Beberapa contoh bentuk TRLP diantaranya pendekatan minimalisasi limbah dan tindakan pencegahan; pendekatan DFE (design for environment); pendekatan product stewardship; dan pendekatan FCA (Full Cost Accounting).

Sejumlah penelitian terdahulu menemukan beberapa faktor pendorong (anteseden) yang memotivasi perusahaan menerapkan TRLP baik dari faktor internal dan eksternal. Beberapa faktor internal tersebut diantaranya persepsi pimpinan atas masalah lingkungan, dimana pemilihan strategi TRLP bergantung pada interpretasi manajer dalam melihat masalah lingkungan, apakah dipandang sebagai peluang atau ancaman (Yang et al., 2018) dan implementasi strategi lingkungan biasanya dimulai dari manajemen puncak (Mak \& Chang, 2019). Faktor internal lain adalah struktur kepemilikan perusahaan baik kepemilikan yang bersumber dari non-swasta (Calza, Profumo, \& Tutore, 2016) maupun dari swasta (Darnall, Henriques, \& Sadorsky, 2010) seperti perusahaan multinasional yang terbukti mendorong percepatan penerapan TRLP melalui transfer pengetahuan antar berbagai divisi (González-Benito \& González-Benito, 2006). Selain itu, ukuran perusahaan dan ketersediaan sumber daya perusahaan juga dapat mendorong penerapan TRLP, semakin besar kapasitas sumber daya yang dimiliki perusahaan maka semakin mudah menerapkan strategi proaktif (Darnall et al., 2010; Moon \& Bae, 2011). Adapun beberapa faktor eksternal pendorong TRLP adalah adanya tekanan pemerintah melalui kebijakannya, misalnya pemerintah memberlakukan sanksi atau denda bagi perusahaan yang terbukti melanggar regulasi lingkungan (Liu et al., 2015) atau tekanan dari supply chain partner yang menuntut agar perusahaan menerapkan tindakan yang sama (Zhang, Bi, Yuan, Ge, Liu, \& Bu, 2008).

Pada ruang lingkup konsekuen, beberapa penelitian menemukan bahwa perusahaan yang menerapkan strategi TRLP terbukti mampu membantu perusahaan menciptakan kemampuan (capabilities) baru yang bernilai (valuable) (Sharma \& Vredenburg, 1998), membangun keunggulan daya bersaing (Arragon- Correa \& Sharma, 2003) baik yang menggunakan pendekatan efisiensi biaya maupun diferensiasi (López-Gamero \& Molina-Azorín, 2016). Selain itu, strategi proaktif dapat berdampak positif terhadap kinerja keuangan perusahaan baik pada pertumbuhan penjualan maupun profit (Menguc et al., 2010). Mengacu pada Menguc, Auh, dan Ozanne (2010) perusahaan yang secara proaktif mengelola lingkungan dapat digunakan sebagai katalisator untuk menghasilkan peluang pertumbuhan di masa depan. Selain itu, menurutnya srategi proaktif dapat menciptakan ruang pasar yang belum dimanfaatkan sehingga dapat meningkatkan pertumbuhan penjualan dan keuntungan.

\section{Hubungan Tekanan Institusional dan TRLP}

Dalam kerangka teori institusional, struktur dan tindakan perusahaan sangat dipengaruhi oleh tekanan sosial diluar organisasi yang membentuk serangkaian aturan negara, norma sosial, dan tradisi (Meyer \& Rowan, 1977). Perusahaan yang berperilaku sesuai dengan aturan dan norma yang ada akan mendapatkan pengakuan sah (legitimasi) dari lingkungan institusionalnya (Guler, Guillén, \& 
Macpherson, 2002). Lingkungan institusional ini akan menentukan serangkaian tindakan yang diambil oleh perusahaan (Liu et al., 2010). Lingkungan institusional perusahaan yang dimaksud mencakup pemerintah, pemasok utama, konsumen, asosiasi profesional, dan organisasi lain yang menghasilkan layanan atau produk serupa (DiMaggio \& Powell, 1983). Karena legitimasi punya peran vital dalam eksistensi perusahaan, maka segala upaya yang dilakukan perusahaan pasti selalu bertujuan untuk mencapai legitimasi sehingga tuntutan legitimasi yang berubah diyakini memainkan peran penting dalam menentukan strategi lingkungan perusahaan (Liu et al., 2010).

Upaya perusahaan untuk mempertahankan legitimasi dari lingkungan institusionalnya telah mengarahkan perusahaan menjadi homogen satu sama lainnya (DiMaggio \& Powell, 1983). Fenomena ini disebut dengan isomorfisme. Isomorfisme adalah proses meniru sturuktur organisasi lain yang bertujuan untuk mencapai legitimasi dan kekutan politik perusahaan dalam rangka mempertahankan eksistensinya terhadap tekanan dari luar perusahaan. DiMaggio dan Powell (1983) membagi tiga sumber terjadinya ismorfisme yaitu tekanan koersif, mimikri, dan normatif.

Tekanan koersif adalah mekanisme isomorfis yang terjadi karena adanya tekanan formal maupun informal pada suatu organisasi, yang berasal dari organisasi lain yang saling terhubung dan budaya dari masyarakat tempat organisasi berfungsi. Dalam konteks tindakan ramah lingkungan, Chen et al. (2009) mengklasifikan tekanan koersif ke dalam dua bentuk yaitu tekanan yang bersifat pemaksaan (imposition) dimana terdapat sanksi hukum jika perusahaan tidak mematuhi aturan yang ada dan tekanan yang bersifat dorongan (inducement) dimana pihak-pihak penting seperti supply chain partner dan konsumen mendorong agar perusahaan menerapkan tindakan ramah lingkungan tertentu. Adapun Clemens dan Douglas (2006) mendefinisikan tekanan koersif sebagai tekanan yang berasal dari regulator yang bertujuan mengharuskan perusahaan agar mengadopsi tindakan atau strategi lingkungan tertentu.

Beberapa penelitian sebelumnya menemukan adanya pengaruh positif tekanan koersif terhadap TRLP (Rivera, 2004; Bansal, 2005; Clemens \& Douglas, 2006; Colwell \& Joshi, 2013) dimana tekanan ini dapat mendorong persahaan untuk menerapkan strategi proaktif. Menurut Liu, Liu, Shishime, Yu, Bi, \& Fujitsuka (2010) pemerintah dapat memberikan pesan yang jelas untuk mendorong strategi proaktif perusahaan dengan memberikan beberapa insentif atau sejak awal mengumumkan persyaratan lingkungan yang wajib dipenuhi oleh perusahaan. Setidaknya terdapat tiga alasan mengapa kekuatan regulasi dapat memicu lahirnya TRLP. Pertama, menghindari adanya peraturan baru yang lebih ketat dan luas (Rugman \& Verbeke, 2000). Kedua, menghindari biaya potensial dan kewajiban hukum yang melekat pada regulasi karena adanya ketidakpastian pendekatan yang digunakan pemerintah (Clemens \& Douglas, 2006). Ketiga, menghindari adanya pengawasan dari pihak regulator (Wright \& Rwabizambagu, 2006). Oleh sebab itu, semakin besar tekanan koersif baik dalam bentuk regulasi dan sanksi dapat mendorong perusahaan untuk menerapkan TRLP.

$\mathrm{H}_{1}$ : Tekanan Koersif berpengaruh positif terhadap Tindakan Ramah Lingkungan Proaktif (TRLP).

Tekanan mimikri adalah mekanisme isomorfis yang lahir karena adanya ketidakpastian di dalam lingkungan perusahaan (organisasi), sehingga untuk mengurangi ketidakpastian tersebut perusahaan akan meniru struktur dan aktivitas perusahaan yang sejenis (Di Maggio \& Powell, 1983). Ketidakpastian lahir ketika tekanan dan dorongan pemangku kepentingan memaksa perusahaan untuk melakukan tindakan tertentu, seperti menanggapi masalah lingkungan dan menuntut perusahaan untuk segera merespon desakan tersebut. Dalam konteks perilaku proaktif, ketidakpastian muncul karena isu perbaikan lingkungan memiliki perubahan ekspektasi yang besar, kompleksitas masalah, dan sulitnya penyelesaian masalah (Bansal, 2005). Ketika suatu organisasi menghadapi masalah seperti tekanan dari pemangku kepentingan dengan penyebab yang ambigu atau solusi yang tidak jelas, maka ketidakpastian inilah yang akan memicu perusahaan untuk melakukan imitasi atau meniru perusahaan lain (DiMaggio \& Powell, 1983). Sebagai contoh, penerapan suatu teknologi pada pengaplikasian strategi proaktif melibatkan ketidakpastian yang cukup besar (Chen, Watson, Boudreau, \& Karahanna, 2009). Ketika teknologi organisasi kurang dipahami, tujuan ambigu, atau 
ketika lingkungan menciptakan ketidakpastian simbolis, organisasi dapat menyesuaikan dirinya pada organisasi lain (DiMaggio \& Powell, 1983).

Menurut Haunschild et al. (1997) dalam Chen et al. (2009), ada tiga alasan fundamental perusahaan melakukan imitasi. Pertama, imitasi berdasarkan banyaknya pihak/perusahaan lain menerapkan tindakan tertentu (frequency based). Kedua, imitasi berdasarkan hasil yang menguntungkan yang telah dicapai oleh peniru lainnya (outcome based). Ketiga, imitasi berdasarkan atribusi penting yang dibagi dengan organisasi lain (trait based).

Beberapa penelitian sebelumnya menemukan adanya hubungan positif pada tekanan mimikri terhadap TRLP (Bansal, 2005). Menurut Bansal (2005) perusahaan cenderung akan meniru aktivitas perusahaan lain yang telah terlihat dan terdefinisi dengan baik, seperti audit lingkungan dan sistem pengelolaan lingkungan yang tersertifikasi, terutama jika kegiatan ini telah dilaporkan ke pihak luar. Dengan meniru, perusahaan dapat memanfaatkan keberhasilan rekan-rekan mereka sehingga perusahaan yang meniru rekan mereka cenderung tidak mengalami sanksi publik atau denda karena legitimasi sering diberikan saat banyak pemain terlibat dalam praktik yang sama (Bansal, 2005). Oleh sebab itu, semakin tinggi tekanan mimikri yang dihadapi perusahan maka semakin besar peluang perusahaan menerapkan TRLP.

$\mathrm{H}_{2}$ : Tekanan Mimikri berpengaruh positif terhadap Tindakan Ramah Lingkungan Proaktif (TRLP).

Tekanan normatif adalah mekanisme isomorfis yang terjadi karena adanya tekanan dari lingkungan jaringan profesional perusahaan (DiMaggio dan Powel, 1983). DiMaggio dan Powell (1983) menafsirkan profesionalisasi adalah usaha pekerja secara kolektif untuk menentukan kondisi dan metode bekerja mereka yang bertujuan untuk mengendalikan "produksi regulator" dan menetapkan basis kognitif serta legitimasi terhadap wewenang pekerjaan mereka. Salah satu bentuk jaringan profesional adalah seperti asosiasi industri. Jaringan profesional atau asosiasi seperti ini akan menghasilkan norma atau aturan yang telah disepakati bersama dan dijadikan pedoman untuk bertindak (Liu et al., 2010).

Menurut Rivera (2004) tekanan normatif berpengaruh positif terhadap TRLP. Perusahaan yang terlibat dalam asosiasi industri tertentu akan bekerja secara kolektif untuk menghindari adanya peningkatan pengawasan dari masyarakat, media, dan regulator. Dengan demikian, perusahaan yang merupakan anggota dari asosiasi industri menghadapi tekanan normatif yang kuat untuk menunjukkan kepemimpinannya pada kinerja lingkungan (Rivera, 2004). Peningkatan pemaksaan ini menyebabkan perusahaan yang lebih ramah lingkungan akan secara tidak langsung menerapkan tekanan tersebut ke seluruh perusahaan di industrinya (Clemens \& Douglas, 2006). Selain itu, Rivera (2004) berpendapat perusahaan yang menjadi bagian dari asosisasi industri menghadapi tekanan normatif yang lebih besar dibanding mereka yang bukan anggota asosiasi. Hal tersebut karena mereka dituntut untuk menjadi teladan perusahaan yang memiliki kinerja lingkungan yang baik kepada perusahaan lain dan untuk mendukung manajemen lingkungan yang proaktif (Delmas \& Toffel, 2004). Oleh sebab itu, keanggotaan suatu perusahaan dalam asosiasi industri dapat mendorong mereka untuk berperilaku proaktif dimana semakin besar dorongan dan tuntutan anggota lain dalam jaringan profesional maka semakin besar kecenderungan perusahaan melakukan tindakan ramah lingkungan proaktif (TRLP).

$\mathrm{H}_{3}$ : Tekanan normatif berpengaruh positif terhadap Tindakan Ramah Lingkungan Proaktif (TRLP).

\section{Hubungan TRLP dan Reputasi Perusahaan}

Untuk menguji bagaimana pengaruh TRLP terhadap reputasi perusahaan, penelitian ini mengunakan kerangka teori sinyal. Menurut Basdeo, Smith, Grimm, Rindova, \& Derfus (2006) pada studi reputasi perusahaan, teori sinyal digunakan untuk menjelaskan bagaimana sinyal yang dikirim oleh perusahaan dalam bentuk pilihan strateginya dapat membentuk kesan atau anggapan stakeholder dalam menggambarkan perusahaan secara menyeluruh (organizational images). Teori sinyal sering diterapkan dalam studi yang membahas pada tahapan tindakan (action stage) seperti pembentukan, 
pemeliharaan, dan upaya mempertahankan reputasi berdasarkan images yang telah diproyeksikan oleh perusahaan (Walker, 2010).

Reputasi perusahaan merupakan seperangkat persepsi yang dipegang oleh orang-orang di dalam dan di luar perusahaan (Fombrun \& Gardberg, 2000). Perusahaan publik umumnya berusaha untuk memenuhi tuntutan berbagai kelompok pemangku kepentingan agar memiliki reputasi yang baik dan diterima dalam beroperasi oleh masyarakat (Miles \& Covin, 2000). Meningkatnya perhatian publik di seluruh dunia tentang perlindungan lingkungan menjadikan kinerja lingkungan sebagai salah satu dimensi terpenting dari penilaian reputasi perusahaan (Wright \& Rwabizambuga, 2006). Pelanggaran terhadap standar peraturan dan norma sosial akan menimbulkan persepsi negatif dari publik yang pada akhirnya berdampak buruk bagi citra atau reputasi perusahaan (Liu et al., 2015).

Menurut Basdeo et al. (2006) pembentukan reputasi dapat dipahami secara luas sebagai proses pensinyalan, perusahaan mengirim sinyal kepada pengamat dalam bentuk pilihan strateginya dan pengamat menggunakan sinyal tersebut untuk membentuk kesan tehadap perusahaan. Sinyalsinyal ini membentuk reputasi perusahaan karena memungkinkan para pemangku kepentingan untuk membentuk kesan dan pendapat tentang kemampuannya untuk menciptakan nilai bagi mereka. Sehingga pilihan strategi menjadi faktor penting dalam membentuk reputasi. Perusahaan yang menerapkan TRLP memberikan isyarat (sinyal) kepada pemangku kepentingan (stakeholder) bahwa perusahaan berkomitmen terhadap masalah lingkungan yang telah menjadi perhatian publik bahkan beroperasi secara lebih bertanggung jawab dibandingkan perusahaan yang lain. Selain itu, informasi ini memainkan peran di pasar kompetitif dalam membangun status reputasi perusahaan yang lebih tinggi dengan memberikan sinyal kepada pemangku kepentingan bahwa perusahaan lebih baik dari pesaing (Wright \& Rwabizambuga, 2006).

Penelitian Yang, Hong, \& Modi (2011) membuktikan strategi proaktif terbukti memiliki andil dalam membangun reputasi perusahaan. Lebih lanjut, perusahaan yang melakukan TRLP dapat meraih reputasi yang lebih baik dibanding perusahaan yang tidak menerapkan strategi yang sama (Delmas \& Toffel, 2004). Oleh sebab itu, perusahaan dapat membangun reputasi yang lebih baik dari pesaing dengan menunjukkan tanggung jawab yang lebih terhadap lingkungan (Heikkurinen, 2010). Sehingga, semakin perusahaan proaktif terhadap masalah lingkungan maka semakin baik reputasi yang dimiliki perusahaan.

$\mathrm{H}_{4}$ : Tindakan Ramah Lingkungan Proaktif (TRLP) berpengaruh positif terhadap reputasi perusahaan.

\section{Metode Penelitian}

Jenis Penelitian

Studi ini termasuk penelitian eksplanatori yang bertujuan untuk menguji sejumlah hipotesis yang dibangun (Cooper \& Schlinder, 2014). Pendekatan yang digunakan bersifat kuantitatif karena proses untuk membuktikan pengaruh dari tiap variable yang diangkat dilakukan melalui proses pengujian statistik yang relevan.

\section{Pemilihan Sampel \& Pengumpulan Data}

Populasi penelitian terdiri dari perusahaan di Indonesia pada berbagai sektor industri yang bertujuan untuk meningkatkan generalisasi temuan penelitian. Unit analisis menggunakan level perusahaan baik yang beroperasi pada tingkat induk maupun subsidiary karena masing-masing unit memiliki karakteristik tertentu sehingga dapat memengaruhi efek dari tekanan institusional (Delmas \&Toffel, 2004).

Teknik pemilihan sampel menggunakan purposive sampling dengan kriteria mengacu pada peraturan kementerian lingkungan hidup No. 6 tahun 2013 yaitu perusahaan yang memiliki dokumen lingkungan seperti AMDAL dan UKL-UPL; memiliki skala kegiatan yang cukup signifikan menimbulkan dampak lingkungan; dan menjadi perhatian masyarakat baik dalam lingkup regional 
maupun nasional. Untuk memeroleh data perusahaan berdasarkan kriteria tersebut, penulis merujuk pada laporan PROPER, database pemerintah regional maupun nasional.

Data yang digunakan bersifat sekali waktu melalui penyebaran kuesioner yang diperoleh secara langsung dari responden. Responden yang mengisi kuesioner merupakan individu informan kunci dari perusahaan yang mengetahui dan memiliki informasi pokok berkaitan dengan penelitian. Individu tersebut dapat berada pada posisi manajemen puncak atau menengah. Pengumplan data dilakukan selama Desember 2017 hingga April 2018. Dari 170 kuesioner yang didistribusikan, sebanyak 76 kuesioner layak untuk dianalisis.

Tabel 1. Karakteristik Responden

\begin{tabular}{|c|c|c|c|}
\hline Profil Perusahaan & Persentase $(\%)$ & Profil Informan Kunci & Persentase (\%) \\
\hline Status Perusahaan & & Jenis Kelamin & \\
\hline Perusahaan Induk & 41 & Laki-Laki & 65 \\
\hline Perusahaan Cabang & 21 & Perempuan & 35 \\
\hline \multirow[t]{2}{*}{ Anak Perusahaan } & 38 & & \\
\hline & & Usia & \\
\hline Sektor Perusahaan & & 20-29 tahun & 18 \\
\hline Pertanian, Kehutanan dan Perikanan & 1 & 30-39 tahun & 30 \\
\hline Manufaktur & 9 & 40-49 tahun & 32 \\
\hline Retail & 5 & $>50$ tahun & 20 \\
\hline Transportasi \& Pergudangan & 7 & & \\
\hline Restoran, Perhotelan \& Pariwisata & 60 & Pendidikan Terakhir & \\
\hline Kesehatan & 11 & SMA/ Sederajat & 3 \\
\hline Informasi \& Komunikasi & 3 & Diploma & 24 \\
\hline \multirow[t]{2}{*}{ Properti } & 4 & Sarjana & 60 \\
\hline & & Magister & 13 \\
\hline \multicolumn{4}{|l|}{ Skala Operasi } \\
\hline Lokal/Regional & 41 & Jabatan/Posisi & \\
\hline Nasional & 46 & Direktur Utama & 14 \\
\hline \multirow[t]{2}{*}{ Multinasional } & 13 & Direktur Bidang & 12 \\
\hline & & Manajer Divisi & 54 \\
\hline Jumlah Karyawan Tetap & & Staf Ahli & 20 \\
\hline $0-49$ orang & 37 & & \\
\hline 50-99 orang & 25 & & \\
\hline 100-499 orang & 28 & & \\
\hline 500-1000 orang & 3 & & \\
\hline$>1000$ orang & 7 & & \\
\hline
\end{tabular}

Operasionalisasi Variabel

Definisi operasional variabel penelitian dapat dijelaskan pada Tabel 2. 
Tabel 2. Operasionalisasi Variabel Penelitian

\begin{tabular}{|c|c|c|c|c|}
\hline Variabel & Definisi Operasional & Sumber & Item & Skala \\
\hline Tekanan Koersif & $\begin{array}{l}\text { Pemahaman organisasi mengenai } \\
\text { konsekuensi formal yang diterima } \\
\text { ketika tidak mematuhi peraturan } \\
\text { lingkungan hidup. }\end{array}$ & Jaffe (2001) & 4 & $\begin{array}{l}5 \text { skala } \\
\text { likert }\end{array}$ \\
\hline Tekanan Mimikri & $\begin{array}{l}\text { Kesadaran organisasi mengenai } \\
\text { tindakan lingkungan dari para } \\
\text { pemimpin industri. }\end{array}$ & Jaffe (2001) & 3 & $\begin{array}{l}5 \text { skala } \\
\text { likert }\end{array}$ \\
\hline Tekanan Normatif & $\begin{array}{l}\text { Norma kolektif yang berlaku dalam } \\
\text { menangani masalah lingkungan. }\end{array}$ & $\begin{array}{l}\text { DiMaggio \& } \\
\text { Powel (1983) }\end{array}$ & 3 & $\begin{array}{l}5 \text { skala } \\
\text { likert }\end{array}$ \\
\hline TRLP & Tindakan pencegahan limbah & $\begin{array}{l}\text { Menguc et al. } \\
(2010)\end{array}$ & 10 & $\begin{array}{l}5 \text { skala } \\
\text { likert }\end{array}$ \\
\hline Reputasi Perusahaan & $\begin{array}{l}\text { Persepsi umum perusahaan mengenai } \\
\text { reputasinya }\end{array}$ & $\begin{array}{l}\text { Weiss et al. } \\
(1999)\end{array}$ & 5 & $\begin{array}{l}5 \text { skala } \\
\text { likert }\end{array}$ \\
\hline
\end{tabular}

\section{Analisis Data}

Pengujian validitas instrumen melalui beberapa tahap. Pertama, melakukan face dan content validity kepada ahli yaitu akademisi sekaligus praktisi dalam program sertifikasi kelayakan AMDAL perusahaan. Validasi ini bertujuan untuk memastikan kesesuaian translasi yang dilakukan peneliti pada instrumen, sebab variabel yang digunakan (e.g TRLP) cukup asing sehingga peneliti merasa perlu melakukan konsultasi pada ahli (akademisi) dari bidang keilmuan terkait atau yang relevan dengan topik penelitian. Kedua, melakukan pengujian Confrimatory Factor Analysis (CFA) dengan menggunakan penilaian Kaiser-Meyer Olkin Measure of Sampling Adequency (KMO-MSA) dan Barlett's Test of Sphericity (BTS). Nilai KMO-MSA pada tabel 3.2 adalah 0,825 $(\geq 0,5)$ dan nilai BTS signifikan $(p) 0,000(<0,05)$. Hasil ini berarti bahwa instrumen pengukuran telah memenuhi syarat kecukupan sampel dan setiap indikator telah terpenuhi untuk dapat dilakukan analisis faktor.

Tabel 3. Hasil Pengujian Validitas (CFA) \& Nilai Cronbach Alpha

\begin{tabular}{|c|c|c|c|}
\hline Konstruk dan Item Pertanyaan & Kode & CFA & $\alpha$ \\
\hline \multicolumn{4}{|l|}{ Tekanan Koersif } \\
\hline $\begin{array}{l}\text { Ada konsekuensi negatif bagi perusahaan yang gagal mematuhi undang- } \\
\text { undang lingkungan pusat dan provinsi. }\end{array}$ & TK1 & 0,789 & 0,832 \\
\hline $\begin{array}{l}\text { Perusahaan yang tidak memenuhi standar pengendalian lingkungan yang } \\
\text { telah ditetapkan akan menghadapi ancaman penuntutan hukum yang } \\
\text { signifikan. }\end{array}$ & TK2 & 0,843 & \\
\hline $\begin{array}{l}\text { Perusahaan menyadari adanya potensi denda dan hukuman atas perilaku } \\
\text { lingkungan yang tidak bertanggung jawab. }\end{array}$ & TK3 & 0,803 & \\
\hline $\begin{array}{l}\text { Jika perusahaan melakukan suatu pelanggaran lingkungan, konsekuensinya } \\
\text { kemungkinan akan diberikan laporan negatif oleh analis pasar industri / } \\
\text { saham. }\end{array}$ & TK4 & 0,612 & \\
\hline \multicolumn{4}{|l|}{ Tekanan Mimikri } \\
\hline $\begin{array}{l}\text { Perusahaan terkemuka di industri kami bekerja untuk mengurangi } \\
\text { dampaknya terhadap lingkungan. }\end{array}$ & TM1 & 0,718 & 0,813 \\
\hline $\begin{array}{l}\text { Perusahaan terkemuka di industri kami telah memberi contoh untuk } \\
\text { melakukan perilaku yang bertanggung jawab terhadap lingkungan. }\end{array}$ & TM2 & 0,743 & \\
\hline $\begin{array}{l}\text { Perusahaan terkemuka di industri kami dikenal karena praktik mereka yang } \\
\text { mempromosikan pelestarian lingkungan. }\end{array}$ & TM3 & 0,798 & \\
\hline
\end{tabular}




\begin{tabular}{|c|c|c|c|}
\hline Konstruk dan Item Pertanyaan & Kode & CFA & $\alpha$ \\
\hline $\begin{array}{l}\text { Industri kami memiliki asosiasi industry/ professional yang mendorong } \\
\text { perusahaan dalam industri untuk menjadi lebih bertanggung jawab } \\
\text { terhadap lingkungan }\end{array}$ & TN1 & 0,767 & 0,893 \\
\hline $\begin{array}{l}\text { Industri kami mengharapkan semua perusahaan dalam industri bertanggung } \\
\text { jawab terhadap lingkungan }\end{array}$ & TN2 & 0,844 & \\
\hline $\begin{array}{l}\text { Bertanggung jawab terhadap lingkungan adalah persyaratan bagi } \\
\text { perusahaan untuk menjadi bagian dari asosiasi ini. }\end{array}$ & TN3 & 0,802 & \\
\hline \multicolumn{4}{|l|}{ Tindakan Ramah Lingkungan Proaktif (TRLP) } \\
\hline $\begin{array}{l}\text { Menghilangkan pelepasan zat apapun yang dapat menyebabkan kerusakan } \\
\text { lingkungan }\end{array}$ & TRLP1 & 0,678 & 0,853 \\
\hline Melindungi semua habitat alami yang terkena dampak operasi perusahaan & TRLP2 & 0,628 & \\
\hline $\begin{array}{l}\text { Menggunakan sumber daya alam yang terbarukan secara terus } \\
\text { menerus/berkelanjutan }\end{array}$ & TRLP3 & 0,568 & \\
\hline $\begin{array}{l}\text { Melestarikan sumber daya alam yang tidak terbarukan (misalnya Oli, gas } \\
\text { alam) }\end{array}$ & TRLP4 & 0,638 & \\
\hline Menghilangkan limbah fisik dari operasi & TRLP5 & 0,581 & \\
\hline Mengurangi limbah fisik melalui daur ulang & TRLP6 & - & \\
\hline Membuang limbah fisik melalui metode yang aman bagi lingkungan & TRLP7 & 0,629 & \\
\hline $\begin{array}{l}\text { Menghilangkan penggunaan produk yang menyebabkan kerusakan } \\
\text { lingkungan }\end{array}$ & TRLP8 & 0,667 & \\
\hline $\begin{array}{l}\text { Menginformasikan pelanggan kami mengenai dampak lingkungan dari } \\
\text { produk yang dipasarkan }\end{array}$ & TRLP9 & 0,745 & \\
\hline Memperbaiki kondisi yang membahayakan lingkungan & TRLP10 & - & \\
\hline \multicolumn{4}{|l|}{ Reputasi Perusahaan } \\
\hline $\begin{array}{l}\text { Perusahaan Kami dilihat pelanggan sebagai organisasi yang sangat } \\
\text { profesional }\end{array}$ & RP1 & 0,835 & 0,867 \\
\hline $\begin{array}{l}\text { Perusahaan kami dipandang oleh pelanggan sebagai perusahaan yang } \\
\text { sukses }\end{array}$ & RP2 & 0,900 & \\
\hline Reputasi perusahaan kami sangat dihargai. & RP3 & 0,685 & \\
\hline Pelanggan menganggap perusahaan kami sebagai perusahaan yang stabil & RP4 & 0,788 & \\
\hline Perusahaan kami dipandang mapan oleh pelanggan. & RP5 & - & \\
\hline
\end{tabular}

Pada tabel ketiga, standar nilai factor loading yang digunakan sebesar $>0,5$ yang berarti itemitem pernyataan valid secara signifikan. Dari 25 item pernyataan terdapat 3 indikator yang dieliminasi karena mengalami cross loading sehingga item pernyataan yang dapat digunakan 23 item dengan nilai factor loading rata-rata > 0,56 yaitu TRLP6, TRLP10 dan RP5. Selain itu, koefisien Cronbach alpha pada masing-masing variabel berkisar antara $0,81-0,89$ yang berarti reliabilitas dapat diterima.

Tabel 4. Nilai Rerata, Standar Deviasi dan Koefisien Korelasi antar Variabel

\begin{tabular}{lccccccc}
\hline \multicolumn{1}{c}{ Variabel } & $\mathrm{M}$ & $\mathrm{SD}$ & 1 & 2 & 3 & 4 & 5 \\
\hline Tekanan koersif & 4,046 & 0,576 & 1 & & & & \\
Tekanan mimikri & 4,105 & 0,581 & $0,465^{* *}$ & 1 & & & \\
Tekanan normatif & 4,057 & 0,667 & $0,417^{* *}$ & $0,499^{* *}$ & 1 & & \\
TRLP & 4,160 & 0,471 & $0,443^{* *}$ & $0,520^{* *}$ & $0,583^{* *}$ & 1 & \\
Reputasi perusahaan & 4,397 & 0,507 & $0,358^{* *}$ & $0,367^{* *}$ & $0,305^{* *}$ & $0,404^{* *}$ & 1 \\
\hline
\end{tabular}

**. Korelasi signifikan pada tingkat 0,01 (2 tailed)

Pengujian hipotesis dilakukan menggunakan analisis regresi berganda (H1- H3) dan analisis regresi sederhana (H4). Sesuai dengan prosedur analisis yang dijelaskan oleh Hair et al. (2014) bahwa sebelum melakukan analisis regresi berganda terdapat beberapa syarat statistik yang harus dipenuhi sehingga perlu dilakukan beberapa uji asumsi klasik. Tujuannya adalah untuk memastikan bahwa 
persamaan regresi yang diperoleh memiliki ketepatan dalam estimasi, tidak bias dan konsisten. Hasil uji multikolinearitas menunjukkan nilai tolerance masing-masing variabel lebih besar dari 0,10 dan nilai VIF masing-masing variabel tidak lebih besar dari 10 sehingga dapat disimpulkan bahwa model regresi bebas dari gejala multikolinearitas atau tidak terdapat hubungan linear diantara variabel bebas dalam model penelitian.

Tabel 5. Hasil Uji Multikolinearitas

\begin{tabular}{lll}
\hline Variabel & Nilai Tolerance & VIF \\
\hline Tekanan Koersif & 0,738 & 1,355 \\
Tekanan Mimikri & 0,671 & 1,491 \\
Tekanan Normatif & 0,707 & 1,414 \\
\hline
\end{tabular}

Hasil dan Pembahasan

Pengujian $\mathrm{H} 1$ yaitu pengaruh tekanan koersif terhadap TRLP menunjukkan pengaruh positif ( $\beta=$ $0,142)$ dengan signifikansi sebesar $0,116(p>0,05)$ yang berarti $\mathrm{H} 1$ tidak didukung. Pada $\mathrm{H} 2$, hasil analisis regresi berganda pada pengaruh tekanan mimikri terhadap TRLP menunjukkan nilai $(\beta=$ $0,213)$ dan tingkat signifikansi $0,025(p<0,05)$ yang berarti terdapat pengaruh positif signifikan pada variabel tekanan mimikri terhadap TRLP sehingga H2 didukung. Pengujian H3 yaitu pengaruh tekanan normatif terhadap TRLP menunjukkan pengaruh positif $(\beta=0,291)$ dengan nilai signifikansi sebesar $0,000(p<0,005)$. Selanjutnya, H4 menunjukkan bahwa variabel TRLP berpengaruh positif terhadap reputasi perusahaan dengan nilai koefisien variabel TRLP $(\beta=0,406)$ dengan tingkat signifikansi sebesar 0,000 $(p<0,05)$ sehingga secara statistik H4 didukung.

Tabel 5. Hasil Pengujian Regresi

\begin{tabular}{llll}
\hline \multicolumn{1}{c}{ Model } & $\boldsymbol{\beta}$ & $\mathrm{t}$ & Sig. \\
\hline Tekanan Koersif $\rightarrow$ TRLP &, 142 & 1,590 &, 116 \\
Tekanan Mimikri $\rightarrow$ TRLP &, 213 & 2,288 &, 025 \\
Tekanan Normatif $\rightarrow$ TRLP &, 291 & 3,682 &, 000 \\
TRLP $\rightarrow$ Reputasi Perusahaan &, 406 & 3,795 &, 000 \\
\hline
\end{tabular}

Meskipun secara parsial tekanan koersif tidak berpengaruh signifikan terhadap TRLP, namun hasil uji simultan (lihat tabel 6) menunjukkan bahwa ketiga variabel independen secara simultan $\left(\mathrm{R}^{2}=\right.$ $0,43)$ berpengaruh positif terhadap TRLP dan signifikan sebesar $0,000(p<0,05)$. Sehingga dapat disimpulkan tekanan institusional (koersif, mimikri, dan normatif) memengaruhi TRLP sebesar 43\% adapun sisanya dipengaruhi oleh variabel lain di luar penelitian.

Tabel 6. Ringkasan Model

\begin{tabular}{ccccccc}
\hline Model & $\mathrm{R}$ & R Square & $\begin{array}{c}\text { Adjusted R } \\
\text { Square }\end{array}$ & $\begin{array}{c}\text { Std. Error of the } \\
\text { Estimate }\end{array}$ & $\mathrm{F}$ & Sig. \\
\hline 1 &, $655^{\mathrm{a}}$ & 0,430 & 0,460 & 0,384438 & 18,068 &, $000^{\mathrm{b}}$ \\
\hline
\end{tabular}

Berdasarkan hasil analisis regresi yang dilakukan terdapat satu hipotesis yang tidak terdukung yaitu H1. Tidak terdukungnya hipotesis ini mengkonfrimasi penelitian Singh et al. (2012) yang juga menemukan tekanan regulasi di India tidak memengaruhi TRLP. Padahal di beberapa negara lain tekanan regulasi merupakan faktor penting yang mendorong penerapan TRLP (lihat Rivera, 2004; Bansal, 2005; Clemen \& Douglas, 2006). Melalui kajian literatur yang dilakukan, peneliti menemukan setidaknya terdapat empat argumentasi menjelaskan temuan ini.

Pertama, bervariasinya pengaruh anteseden (tekanan regulasi) terhadap TRLP, disebabkan kondisi makro seperti sistem bisnis dan lingkungan industri yang melekat pada suatu wilayah bersifat 
heterogen sehingga tanggapan perusahaan terhadap tekanan regulasi beragam tergantung pada konteks wilayah perusahaan berada (Liu et al., 2015; Xia-He, Xing Shen, Bin Li, Chun Xu, Zhao, \& Yin Long, 2018). Lebih lanjut, karena penelitian ini dilakukan pada perusahaan yang berada di Indonesia maka pengaruh tekanan regulasi terhadap TRLP memberikan efek yang berbeda dari penelitian-penelitian sebelumnya (Rivera, 2004; Bansal, 2005; Clemen \& Douglas, 2006; Yang et al., 2018). Kedua, terdapat perbedaan kekuatan regulasi antara negara maju dan berkembang (Xia-He et al., 2018). Negara berkembang umumnya memiliki regulasi yang kurang ketat dan belum ditetapkan dengan baik (Chu, Xu, Lai, \& Collins, 2018) khususnya pada regulasi yang berkaitan dengan masalah lingkungan (Sandhu, Smallman, Ozanne, \& Cullen, 2012). Hal ini dipertegas Hakim (2015) yang menyatakan bahwa penegakan hukum atas pelanggaran lingkungan yang telah diatur dalam UU No. 32 tahun 2009 masih sulit dilakukan. Sehingga Indonesia sebagai representasi dari negara berkembang masuk pada kategori wilayah yang memiliki regulasi yang kurang ketat khususnya pada masalah lingkungan (Hakim, 2015). Ketiga, perilaku proaktif biasanya hanya dipengaruhi oleh tekanan dari pihak pemangku kepentingan tertentu seperti dari pihak pelanggan, supplier dan shareholder (Henriques dan Sadorsky, 1999). Adapun perilaku reaktif lebih dipengaruhi oleh tekanan dari pihak regulator (Shandhu et al., 2012). Sejalan dengan pendapat Shandu, Smallman, Ozanne, dan Cullen (2012) sistem PROPER pada pelaksanaannya juga memanfaatkan pengaruh pasar dan kekuatan masyarakat untuk memberikan tekanan kepada industri agar meningkatkan kinerjanya dalam pengelolaan lingkungan (PROPER, 2015). Keempat, secara empiris data yang digunakan penelitian ini sebagian besar berasal dari sektor hotel dan pariwisata $(60,5 \%)$ dan rumah sakit (10, $5 \%$ ) yang dinilai PROPER masih memiliki tingkat ketaatan yang rendah (PROPER, 2015). Dengan kata lain, perusahaan yang mengisi kuesioner sebagian besar dari perusahaan yang memang tidak patuh terhadap regulasi yang ada sehingga jawaban yang diberikan berdampak pada hasil penelitian.

Hasil pengujian hipotesis kedua membuktikan bahwa tekanan mimikri berpengaruh positif terhadap TRLP dimana semakin besar tekanan mimikri maka semakin tinggi tingkat penerapan TRLP yang dilakukan perusahaan. Hasil penelitian ini mengkonfirmasi temuan sebelumnya (Bansal, 2005; Liu et al., 2010) yang menemukan bahwa tekanan mimikri mengarahkan perusahaan pada TRLP. Sesuai dengan perspektif isomorfisme (DiMaggio dan Powell, 1983) organisasi akan meniru organisasi serupa baik secara implisif maupun eksplisif yang mereka anggap telah terlegitimasi dan berhasil. Berdasarkan tipologi Haunschild et al. (1997) dalam Chen et al. (2009) setidaknya ada tiga proses meniru (imitasi) yang dilakukan organisasi/perusahaan yaitu imitasi berdasarkan jumlah (frequency based), imitasi berdasarkan hasil (outcomes based) dan imitasi berdasarkan sifat/karakter (trait based). Dalam konteks penelitian ini, mimikri berpengaruh terhadap TRLP didasarkan pada meningkatnya jumlah perusahaan yang menerankan TRLP (PROPER, 2016) sehingga perusahan lain meniru strategi proaktif karena telah banyak perusahaan lain yang melakukannya (frequency based). Lebih lanjut, hasil penelitian ini juga mengkonfirmasi temuan Chen et al. (2009) yang menekankan peran imitasi berbasis hasil (outcomes based) dimana oganisasi termotivasi untuk mengadoposi tindakan tertentu karena hasil yang menguntungkan yang telah dicapai oleh peniru lainnya. Dengan imitasi berbasis hasil, organisasi termotivasi untuk menerapkan tindakan tertentu karena hasil yang menguntungkan telah dicapai oleh pengadopsi lain. Selain itu, tekanan mimikri juga memengaruhi TRLP karena pertimbangan imitasi berdasarkan sifat (trait based) yaitu adanya kesamaan atribusi yang dibagi perusahaan-perusahaan yang memiliki lingkungan institusional yang sama. Hal ini sesuai dengan temuan Zhu, Cordeiro, \& Sarkis (2012) bahwa perusahaan yang berkompetisi pada pasar global memiliki tekanan mimikri yang secara positif mendorong penerapan TRLP.

Hasil analisis regresi $\mathrm{H} 3$ menemukan tekanan normatif memiliki pengaruh positif terhadap TRLP sehingga temuan ini mengkonfirmasi temuan sebelumnya (Rivera, 2004) yang menyatakan hal serupa bahwa tekanan dari jaringan profesional dapat mendorong perusahaan untuk berperilaku TRLP. Kehadiran asosiasi industri memudahkan regulator dan publik untuk mengawasi perilaku perusahaan yang menjadi anggota dari asosiasi tersebut (Delmas, 2004) sehingga perusahaan yang menjadi bagian dari asosiasi industri tertentu menghadapi tekanan normatif yang lebih besar 
dibandingkan perusahaan yang tidak berafiliasi pada asosiasi industri (Rivera, 2004). Penelitian Zhu et al. (2012) menemukan bahwa jaringan internasional antar perusahaan eksportir di Cina memicu adanya perilaku TRLP melalui penyebaran pengetahuan (transfer knowledge). Hal ini terjadi karena perusahaan dituntut menjadi teladan perusahaan yang memiliki kinerja lingkungan yang baik kepada perusahaan lain. Pada konteks penelitian ini, secara statistik perusahaan yang menjadi sampel penelitian didominasi oleh mereka yang terdaftar pada asosiasi industri yakni sebanyak $71,1 \%$ artinya perilaku TRLP perusahaan di Indonesia disebabkan adanya tekanan dari jaringan profesional mereka.

Hasil analisis regresi H4 menemukan TRLP berpengaruh positif terhadap reputasi perusahaan. Hasil penelitian ini mengkonfirmasi temuan Yang et al. (2011) dan Kumar (2018) bahwa TRLP memberikan efek positif bagi reputasi perusahaan. Selain itu, penelitian Martinez dan Rodriguez (2014) juga menemukan bahwa TRLP sebagai bagian dari upaya yang dilakukan perusahaan mewujudkan SGD terbukti memberikan pengaruh positif pada image dan reputasi perusahaan. Penerapan TRLP dapat dijadikan perusahaan sebagai sinyal strategi untuk membentuk atau mempertahankan reputasinya. Lebih lanjut, Wright dan Rwabizambagu (2006) menjelaskan penerapan TRLP adalah upaya untuk memeroleh hingga mempertahankan reputasi positif perusahaan khususnya pada lingkungan institusionalnya. Pada pasar investasi, informasi mengenai baiknya manajemen lingkungan perusahaan terbukti memberikan respon positif pada investor atas perusahaan (Aaron, McMillan, \& Cline, 2012). Secara spesifik, perusahaan yang menerapkan TRLP memberikan isyarat (sinyal) kepada pemangku kepentingan bahwa perusahaan telah berkomitmen terhadap masalah lingkungan yang telah menjadi perhatian publik dan beroperasi secara lebih bertanggung jawab dibandingkan perusahaan yang lain. Selain itu, informasi mengenai strategi proaktif dapat memainkan peran di pasar kompetitif untuk membangun status reputasi perusahaan yang lebih tinggi dengan memberikan sinyal kepada pemangku kepentingan bahwa perusahaan lebih baik dari pesaing (Aaron et al., 2012).

\section{Simpulan}

Penelitian ini memiliki beberapa kontribusi penting. Pertama, penelitian ini memberikan gambaran yang jelas bagaimana peran lingkungan institusional (tekanan koersif, mimikri, dan normatif) dapat mendorong TRLP. Hasil yang diperoleh mengindikasikan bahwa tekanan mimikri dan normatif dapat menjelaskan respon perusahaan atas penerapan TRLP. Adapun tekanan koersif (regulasi) dilaporkan tidak berpengaruh pada penerapan TRLP di Indonesia. Sehingga TRLP yang dilakukan perusahaan pada dasarnya merupakan hasil dari proses meniru (mimikri) perusahaan lain dengan mempertimbangkan jumlah dan manfaat yang diperoleh perusahaan yang ditiru atas tindakan yang TRLP yang dilakukannya. Adapun jaringan profesional (normatif) memungkinkan perusahaan untuk berbagi pengetahuan atas masalah lingkungan yang berimplikasi pada penerapan TRLP.

Kedua, penelitian ini akan memberikan bukti empiris atas asumsi hubungan TRLP dan reputasi perusahaan. Penerapan TRLP terbukti berpengaruh positif bagi pembentukan dan perbaikan reputasi perusahaan dimana tekanan atas permasalahan lingkungan dari publik dapat diterjemahkan perusahaan dengan cara yang lebih menguntungkan seperti dengan menerapkan TRLP sebagai salah satu strategi untuk memperbaiki atau meningkatkan reputasinya di mata masyarakat. Implikasi teoritis atas temuan ini bahwa melalui perspektif teori sinyal, reputasi dapat diraih perusahaan jika menerapkan TRLP.

Ketiga, temuan penelitian akan memperkaya diskusi TRLP dimana sebagian besar penelitian dilakukan pada konteks negara maju seperti Eropa, Amerika, dan Cina. Hasil yang diperoleh mengindikasikan bahwa perusahaan di Indonesia lebih dipengaruhi tekanan pasar (mimikri dan normatif) dibandingkan tekanan pemerintah. Secara praktis, temuan penelitian ini mendorong agar perusahaan sebaiknya menerapkan strategi proaktif karena dapat meningkatkan legitimasi publik khususnya di mata pesaing dan jaringan profesional atas upaya perusahaan untuk lebih bertanggung jawab terhadap lingkungan yang pada akhirnya dapat memperbaiki reputasi perusahaan. 
Kontribusi lain dari penelitian ini adalah memberikan saran bagi regulator (pemerintah Indonesia) untuk membuat suatu kebijakan yang didasarkan pada pemberian insentif yang tidak hanya fokus pada hasil kinerja tingkat perusahaan tetapi atas kinerja tingkat sektor industri. Hal tersebut karena terbukti bahwa peran pesaing dan jaringan profesional dapat mengarahkan perusahaan untuk bertindak proaktif melalui mekanisme isomorfis mimikri dan normatif.

Terdapat beberapa keterbatasan pada penelitian ini. Pertama, penelitian ini hanya mencakup wilayah Jawa dan Sulawesi dimana responden didominasi dari perusahaan yang beroperasi di wilayah Jawa. Implikasinya, sifat sampel pada penelitian ini tidak mampu menghasilkan generalisasi temuan. Penelitian selanjutnya disarankan dapat mengunakan ukuran sampel yang lebih besar yang tersebar secara merata disetiap wilayah. Kedua, peneltian ini hanya menggunakan variabel tekanan institusional untuk menjelaskan anteseden TRLP dari aspek eksternal perusahaan. Oleh karena itu, temuan penelitian dianggap masih belum cukup untuk memberikan gambaran yang komprehensif atas perilaku TRLP di Indonesia. Dengan demikian, untuk upaya pemahaman yang lebih komprehensif penelitian selanjutnya perlu untuk mempertimbangkan faktor lain seperti aspek internal yaitu karakteristik perusahaan atau ukuran perusahaan. Ketiga, temuan bahwa tekanan koersif tidak terdukung pada penelitian ini dapat diuji kembali pada penelitian selanjutnya dengan mempertimbangkan karakteristik variabel makro yang melekat pada regulasi suatu wilayah (Moon \& Bae, 2014) misalnya kondisi politik atau sistem bisnis di Indonesia. Dengan demikian, diharapkan aspek-aspek tersebut dapat memprediksi peran dari tekanan koersif terhadap TRLP secara akurat. Keempat, bukti empiris pada studi TRLP dan reputasi perusahaan masih belum memberikan penjelasan yang komprehensif. Oleh karena itu, diharapkan penelitian selanjutnya dapat menggunakan peran variabel lain dengan menguji hubungan tidak langsung antara strategi proaktif dan reputasi perusahaan atau menggunakan metode pengumpulan data lain seperti data longitudinal. Pengumpulan data pada waktu yang berbeda dapat memberikan pemahaman yang lebih jelas kapan TRLP berperan sebegai pembentuk reputasi dan kapan berperan sebagai pemicu perbaikan reputasi yang sudah ada.

\section{Daftar Pustaka}

Aaron, J. R., McMillan, A., \& Cline, B. N. (2012). Investor reaction to firm environmental management reputation. Corporate Reputation Review, 15(4), 304-318. doi: https://doi.org/10.1057/crr.2012.15.

Aragón-Correa, J. A. (1998). Strategic proactivity and firm approach to the natural environment. Academy of management Journal, 41(5), 556-567. doi: https://doi.org/10.5465/256942.

Aragón-Correa, J. A., \& Sharma, S. (2003). A contingent resource-based view of proactive corporate environmental strategy. Academy of management review, 28(1), 71-88. doi: https://doi.org/10.5465/amr.2003.8925233.

Ateş, M. A., Bloemhof, J., Van Raaij, E. M., \& Wynstra, F. (2012). Proactive environmental strategy in a supply chain context: the mediating role of investments. International Journal of Production Research, 50(4), 1079-1095. doi: https://doi.org/10.1080/00207543.2011.555426.

Bansal, P. (2005). Evolving sustainably: A longitudinal study of corporate sustainable development. Strategic management journal, 26(3), 197-218. doi: https://doi.org/10.1002/smj.441.

Basdeo, D. K., Smith, K. G., Grimm, C. M., Rindova, V. P., \& Derfus, P. J. (2006). The impact of market actions on firm reputation. Strategic Management Journal, 27(12), 1205-1219. doi: https://doi.org/10.1002/smj.556.

Calza, F., Profumo, G., \& Tutore, I. (2016). Corporate ownership and environmental proactivity. Business Strategy and the Environment, 25(6), 369-389. doi: https://doi.org/10.1002/bse.1873. 
Carballo-Penela, A., \& Castromán-Diz, J. L. (2015). Environmental policies for sustainable development: an analysis of the drivers of proactive environmental strategies in the service sector. Business Strategy and the Environment, 24(8), 802-818. doi: https://doi.org/10.1002/bse.1847.

Chen, A. J., Watson, R. T., Boudreau, M. C., \& Karahanna, E. (2009). Organizational adoption of green IS \& IT: An institutional perspective. ICIS 2009 proceedings, Paper 142.

Chu, Z., Xu, J., Lai, F., \& Collins, B. J. (2018). Institutional theory and environmental pressures: The moderating effect of market uncertainty on innovation and firm performance. IEEE Transactions on Engineering Management, 65(3), 392-403. doi: https://doi.org/10.1109/TEM.2018.2794453.

Clemens, B., \& Douglas, T. J. (2006). Does coercion drive firms to adopt 'voluntary'green initiatives? Relationships among coercion, superior firm resources, and voluntary green initiatives. Journal of Business Research, 59(4), 483-491. doi: https://doi.org/10.1016/j.jbusres.2005.09.016.

Colwell, S. R., \& Joshi, A. W. (2013). Corporate ecological responsiveness: Antecedent effects of institutional pressure and top management commitment and their impact on organizational performance. Business Strategy and the Environment, 22(2), 73-91. doi: https://doi.org/10.1002/bse.732.

Cooper, D. R., \& Schindler, P. S. (2014). Business research methods. New York: McGraw- Hill.

Darnall, N., Henriques, I., \& Sadorsky, P. (2010). Adopting proactive environmental strategy: The influence of stakeholders and firm size. Journal of management studies, 47(6), 1072-1094. doi: https://doi.org/10.1111/j.1467-6486.2009.00873.x.

Delmas, M. A. (2002). The diffusion of environmental management standards in Europe and in the United States: An Institutional Perspective. Policy Sciences, 35(1), 91-119. Retrieved from https://link.springer.com.

Delmas, M., \& Toffel, M. W. (2004). Stakeholders and environmental management practices: an institutional framework. Business strategy and the Environment, 13(4), 209-222. doi: https://doi.org/10.1002/bse.409.

DiMaggio, P. J., \& Powell, W. W. (1983). The iron cage revisited: Institutional isomorphism and collective rationality in organizational fields. American sociological review, 147-160. doi: http://www.jstor.org/stable/2095101.

Fombrun, C. J., \& Van Riel, C. B. (1997). The reputational landscape. Corporate reputation review, 1(2), 5-13. Retrieved from https://repub.eur.nl.

Fombrun, C. J., Gardberg, N. A., \& Sever, J. M. (2000). The Reputation Quotient SM: A multistakeholder measure of corporate reputation. Journal of brand management, 7(4), 241-255. doi: https://doi.org/10.1057/bm.2000.10.

Guler, I., Guillén, M. F., \& Macpherson, J. M. (2002). Global competition, institutions, and the diffusion of organizational practices: The international spread of ISO 9000 quality certificates. Administrative science quarterly, 47(2), 207-232. doi: https://doi.org/10.2307/3094804.

González-Benito, J., \& González-Benito, Ó. (2006). A review of determinant factors of environmental proactivity. Business Strategy and the environment, 15(2), 87-102. doi: https://doi.org/10.1002/bse.450.

Hair, J. F., Black, W. C., Babin, B. J., Anderson, R. E. (2010). Multivariate Data Analysis (7 ed). Pearson Education, Inc. . Naskah harus disertai dengan kata kunci (Keyword) dan dua digit nomor Klasifikasi Journal of Economic Literature (JEL). Lihat klasifikasi JEL pada, http:// www.acaweb.org/ journal/jel,_class_system.html. 
Hakim, D. A. (2015). Politik Hukum Lingkungan Hidup di Indonesia Berdasarkan Undang-undang Nomor 32 Tahun 2009 Tentang Perlindungan dan Pengelolaan Lingkungan Hidup. Fiat Justisia, 9(2). doi: https://doi.org/10.25041/fiatjustisia.v9no2.592.

Hart, S. L., \& Dowell, G. (2011). Invited editorial: a natural-resource-based view of the firm: fifteen years after. Journal of management, 37(5), 1464-1479. doi: https://doi.org/10.1177/0149206310390219.

He, Z. X., Shen, W. X., Li, Q. B., Xu, S. C., Zhao, B., Long, R. Y., \& Chen, H. (2018). Investigating external and internal pressures on corporate environmental behavior in papermaking enterprises of China. Journal of Cleaner Production, 172, 1193-1211. doi:https://doi.org/10.1016/j.jclepro.2017.10.115.

Heikkurinen, P. (2010). Image differentiation with corporate environmental responsibility. Corporate social responsibility and environmental management, 17(3), 142-152. doi: https://doi.org/10.1002/csr.225.

Jaffee, D. (2001). Organization theory: Tension and Change. McGraw-Hill Humanities, Social Sciences \& World Languages.

Jennings, P. D., \& Zandbergen, P. A. (1995). Ecologically sustainable organizations: An institutional approach. Academy of management review, 20(4), 1015-1052. doi: https://doi.org/10.5465/amr.1995.9512280034.

Kementrian Lingkungan Hidup dan Kehutanan. (2015). Laporan Publikasi PROPER 2015. Jakarta Timur: Kantor Sekertariat PROPER.

Kementrian Lingkungan Hidup dan Kehutanan. (2016). Laporan Publikasi PROPER 2016. Jakarta Timur: Kantor Sekertariat PROPER.

Kumar, A. (2018). Environmental Reputation: Attribution from Distinct Environmental Strategies. Corporate Reputation Review, 21(3), 115-126. doi: https://doi.org/10.1057/s41299-0180047-6.

Liu, X., Liu, B., Shishime, T., Yu, Q., Bi, J., \& Fujitsuka, T. (2010). An empirical study on the driving mechanism of proactive corporate environmental management in China. Journal of environmental management, 91(8), 1707-1717. doi: https://doi.org/10.1016/j.jenvman.2010.03.011.

Liu, Y., Guo, J., \& Chi, N. (2015). The antecedents and performance consequences of proactive environmental strategy: A meta-analytic review of national contingency. Management and Organization Review, 11(3), 521-557. doi:https://doi.org/10.1017/mor.2015.17.

López-Gamero, M. D., \& Molina-Azorín, J. F. (2016). Environmental management and firm competitiveness: the joint analysis of external and internal elements. Long range planning, 49(6), 746-763. doi:https://doi.org/10.1016/j.Irp.2015.12.002.

Mak, A. H., \& Chang, R. C. (2019). The driving and restraining forces for environmental strategy adoption in the hotel Industry: A force field analysis approach. Tourism Management, 73, 4860. doi: https://doi.org/10.1016/j.tourman.2019.01.012.

Martínez, P., \& del Bosque, I. R. (2014). Sustainability dimensions: A source to enhance corporate reputation. Corporate Reputation Review, 17(4), 239-253. doi: https://doi.org/10.1057/crr.2014.13.

Menguc, B., Auh, S., \& Ozanne, L. (2010). The interactive effect of internal and external factors on a proactive environmental strategy and its influence on a firm's performance. Journal of Business Ethics, 94(2), 279-298. doi: https://doi.org/10.1007/s10551-009-0264-0.

Meyer, J. W., \& Rowan, B. (1977). Institutionalized organizations: Formal structure as myth and ceremony. American journal of sociology, 83(2), 340-363. doi: https://doi.org/10.1086/226550. 
Moon, S. G., \& Bae, S. (2011). State-level institutional pressure, firms' organizational attributes, and corporate voluntary environmental behavior. Society \& Natural Resources, 24(11), 11891204. doi:https://doi.org/10.1080/08941920.2010.546828.

Miles, M. P., \& Covin, J. G. (2000). Environmental marketing: A source of reputational, competitive, and financial advantage. Journal of business ethics, 23(3), 299-311. doi: https://doi.org/10.1023/A:1006214509281.

Rivera, J. (2004). Institutional pressures and voluntary environmental behavior in developing countries: Evidence from the Costa Rican hotel industry. Society and Natural Resources, 17(9), 779-797.doi: https://doi.org/10.1080/08941920490493783.

Rugman, A. M., \& Verbeke, A. (2000). Six cases of corporate strategic responses to environmental regulation. European Management Journal, 18(4), 377-385. doi: https://doi.org/10.1016/S02632373(00)00027-X.

Russo, M. V., \& Fouts, P. A. (1997). A resource-based perspective on corporate environmental performance and profitability. Academy of management Journal, 40(3), 534-559. doi: https://doi.org/10.5465/257052.

Sandhu, S., Smallman, C., Ozanne, L. K., \& Cullen, R. (2012). Corporate environmental responsiveness in India: lessons from a developing country. Journal of Cleaner Production, 35, 203-213. doi: https://doi.org/10.1016/j.jclepro.2012.05.040.

Sharma, S., \& Vredenburg, H. (1998). Proactive corporate environmental strategy and the development of competitively valuable organizational capabilities. Strategic management journal, 729-753. doi: https://doi.org/10.1002/(SICI)1097-0266(199808)19:8<729::AIDSMJ967>3.0.CO;2-4.

Singh, N., Jain, S., \& Sharma, P. (2014). Determinants of proactive environmental management practices in Indian firms: an empirical study. Journal of cleaner production, 66, 469-478. doi: https://doi.org/10.1016/j.jclepro.2013.11.055.

Testa, F., Gusmerottia, N. M., Corsini, F., Passetti, E., \& Iraldo, F. (2016). Factors affecting environmental management by small and micro firms: The importance of entrepreneurs' attitudes and environmental investment. Corporate Social Responsibility and Environmental Management, 23(6), 373-385. doi: https://doi.org/10.1002/csr.1382.

Walker, K. (2010). A systematic review of the corporate reputation literature: Definition, measurement, and theory. Corporate reputation review, 12(4), 357-387. doi: https://doi.org/10.1057/crr.2009.26.

Wright, C., \& Rwabizambuga, A. (2006). Institutional pressures, corporate reputation, and voluntary codes of conduct: An examination of the equator principles. Business and Society Review, 111(1), 89-117. doi: https://doi.org/10.1111/j.1467-8594.2006.00263.x.

Weiss, A.M., Anderson,E.,\& MacInnis, D.J. (1999). Reputation Management as a Motivation For Sales Structure Decisions. Journal of Marketing, 63(4), 74-89. doi: https://doi.org/10.1177/002224299906300407.

Xia He, Z., Xing Shen, W., Bin Li, Q., Chun Xu, S., Zhao, B., Yin Long, R. (2018). Investing External and Internal Pressures on Corporate Environmental Behaviour in Papermaking Enterprise of China. Journal of Cleaner Production. 1193 - 1211. doi: https://doi.org/10.1016/j.jclepro.2017.10.115. 
Yang, D., Wang, A. X., Zhou, K. Z., \& Jiang, W. (2018). Environmental strategy, institutional force, and innovation capability: A managerial cognition perspective. Journal of Business Ethics, 115. doi: https://doi.org/10.1007/s10551-018-3830-5.

Yang, M. G. M., Hong, P., \& Modi, S. B. (2011). Impact of lean manufacturing and environmental management on business performance: An empirical study of manufacturing firms. International Journal of Production Economics, 129(2), 251-261. doi: https://doi.org/10.1016/j.ijpe.2010.10.017.

Zhang, B., Bi, J., Yuan, Z., Ge, J., Liu, B., \& Bu, M. (2008). Why do firms engage in environmental management? An empirical study in China. Journal of Cleaner Production, 16(10), 10361045. doi: https://doi.org/10.1016/j.jclepro.2007.06.016.

Zhu, Q., Cordeiro, J., \& Sarkis, J. (2012). International and domestic pressures and responses of Chinese firms to greening. Ecological Economics, 83, 144-153. doi:https://doi.org/10.1016/j.ecolecon.2012.04.007. 